\title{
Why consumers drink natural wine? Consumer perception and information about natural wine
}

\author{
Riccardo Vecchio ${ }^{1}$, Eva Parga-Dans ${ }^{2 *}$, Pablo Alonso González² and Azzurra Annunziata ${ }^{3}$
}

\author{
* Correspondence: eva.parga.dans@ \\ ipna.csic.es \\ ${ }^{2}$ Instituto de Productos Naturales y \\ Agrobiología (IPNA-CSIC), Avda. \\ Astrofísico Francisco Sánchez, 3, \\ 38206 La Laguna, Santa Cruz de \\ Tenerife, Spain \\ Full list of author information is \\ available at the end of the article
}

\begin{abstract}
Similar to other foods, the concept of natural wine is much debated due to the lack of a clear and regulated definition, leading to a proliferation of heterogeneous norms and standards proposed from different natural wine associations at national levels. The current study explored the aspects which mediate individuals' information and perception of natural wine, and the rationale behind natural wine consumption behavior among Italian $(n=501)$ and Spanish $(n=527)$ regular wine consumers. The results reveal a quite low self-reported degree of perceived information by Italian respondents and slightly higher levels among Spanish ones. The key drivers of natural wine consumption in both countries are wine consumption frequency, information, and natural product interest. In contrast, higher wine involvement levels decrease natural wine consumption frequency in both Italy and Spain. The findings also show that different perceptions lead to diverse motivations, suggesting the need for more homogeneous standards to mitigate the level of information asymmetry currently on the market.
\end{abstract}

Keywords: Regular wine consumers, Natural wine, Italy, Spain, Online survey

\section{Introduction}

The growing awareness of public opinion about the linkage between food and health, as well as on the negative effects that traditional food production practices have on environmental resources, has triggered consumers to be more selective and pay more attention to which components and ingredients are used in the food products they eat in everyday life (Asioli et al. 2017).

Consequently, the demand for natural products has grown considerably over the last decade among consumers. The notion of "natural" has become one of the leading label claims on new food products launched to satisfy new consumer demands and market niches (Roman et al. 2017; Hemmerling et al. 2016). However, a universally accepted definition of food naturalness does not exist, and thus, the naturalness of a food product is still a rather vague concept (Roman et al. 2017; Rozin 2006). Undoubtedly, naturalness leads consumers to perceive food products as healthier and more environmentally friendly than conventional ones (Rozin et al. 2012; Caracciolo et al. 2019) but

(c) The Author(s). 2021 Open Access This article is licensed under a Creative Commons Attribution 4.0 International License, which permits use, sharing, adaptation, distribution and reproduction in any medium or format, as long as you give appropriate credit to the original author(s) and the source, provide a link to the Creative Commons licence, and indicate if changes were made. The images or other third party material in this article are included in the article's Creative Commons licence, unless indicated otherwise in a credit line to the material. If material is not included in the article's Creative Commons licence and your intended use is not permitted by statutory regulation or exceeds the permitted use, you will need to obtain permission directly from the copyright holder. To view a copy of this licence, visit http://creativecommons.org/licenses/by/4.0/. 
also tastier, evoking an enhanced hedonic experience (Chambers and Castro 2018; Siegrist and Hartmann 2020).

The search for naturalness has also affected the wine market (Wine Intelligence 2021). Consumer preferences are gradually more influenced by aspects of wine linked to personal healthiness and product sustainability, and this in turn impacts the quality differentiation strategies developed by firms (Pomarici and Vecchio 2019; Schäufele and Hamm 2017). Indeed, the increasing amount of low-intervention, additive, and processing aid-free wines represents a strong trend in several important markets (Wine Intelligence 2021). Natural wine consumption has increased especially among more conscious and responsible consumers, as suggested by recent empirical researches (Galati et al. 2019; Migliore et al. 2020). Furthermore, various producers' associations and organizations are actively promoting natural wine, among them are the Asociación de Productores de Vino Natural and Vella Terra in Spain and Triple A, Viniveri, VinNatur, and Vignaioli Artigianali Naturali (VAN) in Italy (Catellani 2015).

Natural wines are also attracting increased attention among wine critics, giving rise to a surge in books, specialized events, and films about them (Feiring and Choksi 2019; Nossiter 2019; Legeron 2018; Goode and Harrop 2011). Similar to other foods, however, the concept of natural wine is highly debated in the literature due to the lack of a clear and regulated definition. This has led to a proliferation of heterogeneous norms and standards proposed from different natural wine associations at national levels (Alonso González and Parga-Dans 2020; Forbes et al. 2009). Therefore, to date, it is difficult to outline the boundaries of this concept due to the different production philosophies that natural winemakers promote, which have triggered debates among natural winemakers themselves.

Therefore, natural wine should be considered a social movement involving consumers and producers rather than a regulated form of agricultural production (Maykish et al. 2021; Urdapilleta et al. 2021). Only France has recently recognized natural wine as a distinct category and certified it under the denomination Vin Méthode Nature. However, this certification has prompted a heated debate in the European Commission as other EU countries do not agree with the French certification ${ }^{1}$, considering it a form of unfair competition against their own wine sectors. This uncertainty about the meaning of natural wine affects also consumer's perceptions. According to the existing literature, wine is generally perceived to be a natural and environmentally friendly product, as consumers often assume it only includes grapes (De Salvo et al. 2019; Grunert et al. 2018), showing low knowledge about the ingredients, additives, and processing aids that may be used in the production of wine (Pabst et al. 2019; Grunert et al. 2018). Even wine critics tend to associate wine with nature in their tasting rhetoric, with the aim of attracting consumer interest (Black 2013). This is also due to the information asymmetry that dominates the wine sector worldwide (Parga-Dans and Alonso González 2018). The asymmetry derives from the fact that wine has been historically exempted from the mandatory ingredients list other than those that may have an allergenic effect (e.g., sulfites, egg, or fish), generating disinformation and confusion among consumers (Pabst et al. 2021). Nonetheless, according to the latest surveys, European consumers

${ }^{1}$ The French recognition of natural wine itself reflects internal debates and quarrels among natural winemakers, as it comprises two different certifications, one for wines without added sulfites and another for wines with a sulfite content of less than $30 \mathrm{mg} / \mathrm{l}$. 
show a clear concern for food additives and residues (EFSA 2019), which would generate a market niche for natural wine in case it would be recognized as such.

In addition, previous studies showed that consumers tend to associate natural wine conceptualization with organic (Urdapilleta et al. 2021), tend to mistake natural with organic or biodynamic (Delmas and Lessem 2017; Sogari et al. 2016), or to connect the naturalness of wine with the presence of an eco-label (D'Amico et al. 2016). In this context, an in-depth analysis of how consumers perceive natural wine is critical in order to mitigate the level of information asymmetry currently on the market. This could help winemakers, distributors, and retailers to develop more targeted marketing strategies. At the same time, supplementary insights on the drivers of individuals' natural wine consumption could support policymakers in deciding whether regulating the natural wine labeling and foster tailored communication strategies to better address consumers' needs and expectations.

In addition, according to Galati et al. (2019), a cross-country study on this topic could be useful in order to reveal possible opportunities to expand this new market segment.

Consequently, the current paper provides insights on the drivers of natural wine consumption, addressing the following research questions: (i) What are the factors affecting consumer perception of natural wine? (ii) To what extent information and psychographic and socio-demographic variables affect consumers' natural wine consumption?

To this end, a direct survey was performed in Italy and Spain, which according to the International Organization of Vine and Wine (2020) are the two core countries in terms of both wine consumption and production.

\section{Naturalness interest among wine consumers}

While natural wine is increasingly acquiring new consumers in many traditional and non-traditional wine-consuming countries (Wine Intelligence 2021), scholars have devoted limited attention to this specific topic. Nevertheless, several studies have focused on the naturalness of wine indirectly, as an aspect that may influence the perception of healthiness or sustainability of wine (Pappalardo et al. 2019; D'Amico et al. 2016; Kelly et al. 2015). Kelley et al. (2015) showed that the presence of the claim "naturally farmed grapes" in the wine back label information positively affected US consumers' purchasing decisions. In turn, Pappalardo et al. (2019) found that the adoption of production practices related to the higher amount of a natural compound in wine (i.e., resveratrol) increased consumers' demand led by the perception of healthiness in wine. Similarly, D'Amico et al. (2016) revealed that the naturalness of wine affects the health attitude of consumers and represents a relevant factor influencing consumers' willingness to pay a premium price for organic wine without added sulfites.

Considering studies that directly investigated consumers' perception, attitude, and willingness to pay for natural wine, one of the first contributions on the topic is the research from Galati et al. (2019). The authors showed that Italian consumers are willing to pay a premium price for natural wine, especially millennials which are particularly concerned about the environmental and social impacts of their choices. In addition, the authors found that the importance attributed to the label information on ingredient 
contents and sensory characteristics is positively linked to individuals' willingness to pay. Furthermore, Galati et al. (2019) highlighted that consumer WTP for natural wines depends on personal attitudes towards healthy products, without additives or additional ingredients.

Recently, Migliore et al. (2020) found that Italian consumers' interest towards natural wine is strongly affected by individual attitudes towards healthy eating, the environment, and nature, while sensory characteristics and other traditional quality attributes, such as wine color, grape varieties, alcohol content, critics ratings, are not influential. In addition, the authors showed that WTP for natural wine is linked to consumers' interest towards the organic production method as well as to wine sulfite content; on the contrary, WTP is negatively related to the PDO/PGI certifications. An interesting study realized by Staub et al. (2020) assessed what properties of wine influence the perceived naturalness of consumers from two countries, Switzerland and Australia. The authors reveal that naturalness awareness varies according to the country of origin. In addition, individuals with a high level of wine involvement consider naturalness significantly more important than people with a low level of involvement. Furthermore, Swiss results showed that naturalness was the second most important factor for wine choice over price and grape variety. Urdapilleta et al. (2021) also highlighted that cultural differences, personal involvement, and identification with wine strongly affect the social representations of natural, organic, and conventionally produced wines among French and New Zealanders, as well as between wine professionals and consumers. French consumers see organic and natural wines as healthier and associate them with environmental sustainability, while New Zealanders represent natural wines less positively.

In light of the paucity of specific studies on natural wine, there is a need to better understand this specific target of consumers (Alonso González and Parga-Dans 2020) deepening the numerous aspects which mediate individuals' information and perception of natural wine, and the rationale behind their consumption behavior.

\section{Methods}

\section{Questionnaire design and target population}

In order to reach the research objectives, a structured questionnaire was distributed via an online survey management software in Italy and Spain between September and November 2020. Individuals aged between 18 and 70 that consume wine at least once a month were eligible to take part in the survey. Randomization techniques were employed to reduce common method biases associated with online surveys and to enhance the validity of the responses (Vecchio et al. 2020). Individuals participated on a voluntary basis after (1) reading an information sheet in which they were informed about the purposes of the study, (2) advised that the study involved questions about alcoholic beverage consumption, and (3) filled the informed consent form. The research ethics review board of the Spanish National Research Council (CSIC) approved the final questionnaire (approval number 136/2020).

In order to reach the greatest number of responses from the target population, the survey was advertised through wine online forums, wine critics, distributors, and producer associations' webpages and blogs, social networks, and word of mouth. Respectively 501 wine consumers in Italy and 527 in Spain fully completed the questionnaire. 
The questionnaire was divided into five sections: (1) wine consumption habits, (2) natural product interest, (3) perception and information about natural wine, (4) natural wine consumption habits and motivations; and (5) socio-demographic characteristics. Previous research has revealed that consumers tend to mislead natural wines with organic or biodynamic (Delmas and Lessem 2017; Sogari et al. 2016). Thus, to avoid confusion, respondents were shown three pictures with different front and back wine labels, relating to three different types of wine (i.e., organic, biodynamic, and natural) before entering the sections relating to natural wine information, perception, consumption habits, and motivations (namely, sections 4 and 5). The questionnaire was pretested with a pilot sample of 20 individuals in each country in order to check the overall understandability and minor changes were made.

Table 1 provides a summary of the key information collected in the study with the relative measures and literature references. The internal consistency and reliability of the applied scales were measured through Cronbach's alpha, as reported in the "Results" section.

\section{Data analysis}

Collected data were analyzed in two consecutive steps. First, a descriptive analysis was performed applying frequency distributions, means, and standard deviations in order to provide a preliminary overview of the general results. For specific variables, a one-way ANOVA was performed in order to detect the differences among Italian and Spanish

Table 1 Collected data and measurements applied in the current study

\begin{tabular}{|c|c|c|c|}
\hline & Variable & Measurement/scale & References \\
\hline \multirow[t]{3}{*}{ Socio-demographics } & Gender & (1 = male; 0 = female) & \\
\hline & Age & From 18 to 70 & \\
\hline & Education & $\begin{array}{l}\text { From } 1=\text { primary school } \\
\text { to } 4=\text { graduation/master }\end{array}$ & \\
\hline Wine drinking frequency & & $\begin{array}{l}\text { From } 1=\text { at least once a } \\
\text { month to } 5=\text { everyday }\end{array}$ & $\begin{array}{l}\text { Amato et al. (2017); Annunziata } \\
\text { et al. (2016) }\end{array}$ \\
\hline $\begin{array}{l}\text { N. wine glasses consumed } \\
\text { per occasion }\end{array}$ & & $\begin{array}{l}\text { Continuous } \\
\text { From } 1 \text { to } 6\end{array}$ & \\
\hline Wine involvement & 4 items & $\begin{array}{l}\text { From } 1=\text { strongly disagree } \\
\text { to } 5=\text { strongly agree }\end{array}$ & $\begin{array}{l}\text { Adapted from Lockshin et al. } \\
\text { (2001); Chrysochou et al. (2012) }\end{array}$ \\
\hline $\begin{array}{l}\text { Attention towards wine } \\
\text { labeling information }\end{array}$ & $\begin{array}{l}\text { Front label } \\
\text { Back label }\end{array}$ & $\begin{array}{l}\text { From } 1=\text { never pay attention } \\
\text { to } 5=\text { always pay attention }\end{array}$ & $\begin{array}{l}\text { Mueller et al. (2010); Pomarici } \\
\text { et al. (2018) }\end{array}$ \\
\hline Natural product interest & 6 items & $\begin{array}{l}\text { From } 1=\text { strongly disagree } \\
\text { to } 5=\text { strongly agree }\end{array}$ & $\begin{array}{l}\text { Adapted from Roininen et al. } \\
\text { (1999) }\end{array}$ \\
\hline $\begin{array}{l}\text { Self-reported degree of } \\
\text { information on }\end{array}$ & $\begin{array}{l}\text { Natural } \\
\text { wine } \\
\text { Biodynamic } \\
\text { wine } \\
\text { Organic } \\
\text { wine }\end{array}$ & $\begin{array}{l}\text { From } 1=\text { low informed to } \\
5=\text { very informed }\end{array}$ & \\
\hline $\begin{array}{l}\text { Perception of natural wine } \\
\text { attributes }\end{array}$ & 7 items & $\begin{array}{l}\text { From } 1=\text { strongly disagree } \\
\text { to } 5=\text { strongly agree }\end{array}$ & $\begin{array}{l}\text { Adapted from Roman et al. } \\
(2017)\end{array}$ \\
\hline Natural wine consumption & & $(1=$ yes; $0=$ no $)$ & \\
\hline $\begin{array}{l}\text { Natural wine consumption } \\
\text { frequency }\end{array}$ & & $\begin{array}{l}\text { From } 1=\text { at least once a } \\
\text { month to } 5=\text { everyday }\end{array}$ & $\begin{array}{l}\text { Galati et al. (2019); Migliore } \\
\text { et al. (2020) }\end{array}$ \\
\hline $\begin{array}{l}\text { Natural wine consumption } \\
\text { motivations }\end{array}$ & 8items & $\begin{array}{l}\text { From } 1=\text { not at all important } \\
\text { to } 5=\text { very important }\end{array}$ & \\
\hline
\end{tabular}


individuals' behavior. Subsequently, two ordered logistic regressions were performed to identify the drivers that affect natural wine consumption frequency, one for each country.

In order to use the natural wine consumption motivations as explanatory variables in the ordered logistic regressions, two further summary measures were computed with the application of a principal component analysis (PCA) with a varimax rotation to the original items. The two obtained components (with an eigenvalue greater than 1) summarized over $65 \%$ of the original variance (see Table 7 in Appendix). The first component was renamed "sustainability motivation," summarizing the consumption impetus linked to the healthiness and sustainability of natural wine, as well as its handcrafted origin. The second component summarizes instead the reasons related to better taste, easiness of drinking, and less hangover, thus was named "hedonistic motivation." All elaborations were performed with the Stata/SE 15.0 software (StataCorp, College Station, TX, USA).

\section{Results}

\section{Sample description}

Socio-demographic characteristics of both Italian and Spanish samples as well as information related to wine drinking habits are reported in Table 2. The Italian sample includes 501 wine consumers, $54 \%$ are men, and the mean age is 37.5 years old; more than $50 \%$ of the sample is graduated or holds a master's degree. The Spanish sample includes 527 wine consumers, and the incidence of men is about 70\%; the average age is 44.85 and $79 \%$ of respondents graduated or hold a master's degree. Considering the wine consumption habits, most Italian respondents drink wine several times a week (36.7\%) or once a week (12.8\%), consuming about two glasses for occasion. As for the degree of wine involvement, Table 2 shows that Italian respondents are quite in agreement with the statement "I don't need a special occasion to drink wine" ( $M=3.66)$, as well as with the statements "I like giving wine as a gift" $(M=3.59)$ and "I have a strong interest in wine" $(M=3.55)$. Considering the attention paid to the labeling information during wine shopping, Italian respondents tend to pay more attention towards back labeling than to the front labeling.

Twenty-three percent of Spanish respondents drink wine every day and $44.2 \%$ several times a week (consuming, on average, about 2.5 glasses for occasion). Spanish consumers are highly involved with wine, as they strongly agree with the statements "I have a strong interest in wine" $(M=4.73)$ and "I select the wines I purchase very carefully" $(M=4.23)$. They also claim to be very attentive to wine labeling information; both front and back labels received a mean value of 4.2.

\section{Natural product interest}

Respondents' attitude towards natural products was assessed using six items from the Natural Product Interest scale developed by Roininen et al. (1999) and applied in previous research on a similar topic (Migliore et al. 2020) (Table 3). In Italy, the items with the highest scores are "I try to eat foods that do not contain additives" $(M=3.33)$ and "I would like to eat only organically grown vegetables" $(M=2.95)$; however, the mean values for these two statements are higher in Spain (respectively 3.74 and 3.44). In Italy, the item with the lowest score is "Organically grown foods are not better for my health than those grown conventionally" (reversed item, $M=1.94$ ), while in Spain, the lowest score is assigned to the item "I do not care about additives in my daily diet" $(M=1.83)$. 
Table 2 Socio-demographic characteristics and wine consumption habits

\begin{tabular}{|c|c|c|c|}
\hline & & Italy $(n=501)$ & Spain $(n=527)$ \\
\hline \multirow[t]{2}{*}{ Gender (\%) } & Female & 45.3 & 30.9 \\
\hline & Male & 54.7 & 69.1 \\
\hline Mean age (S.D.) & & $37.54(14.48)$ & $44.85(10.27)$ \\
\hline \multirow[t]{5}{*}{ Education (\%) } & Primary & - & 0.5 \\
\hline & Secondary & 5.4 & 2.5 \\
\hline & High school & 38.1 & 17.5 \\
\hline & Graduated/master & 54.3 & 79.5 \\
\hline & n.a. & 2.2 & - \\
\hline \multirow[t]{5}{*}{ Wine drinking frequency (\%) } & Everyday & 12.8 & 23 \\
\hline & Several times a week & 36.7 & 44.2 \\
\hline & Once a week & 21.8 & 17.5 \\
\hline & Several times a month & 13.6 & 9.3 \\
\hline & At least once a month & 15.2 & 6.1 \\
\hline $\begin{array}{l}\text { N. wine glasses consumed } \\
\text { per occasion (mean, S.D.) }\end{array}$ & $\begin{array}{l}\text { Average number of wine glasses } \\
\text { drinked per consumption occasion }\end{array}$ & $2.16(1.03)$ & $2.58(1.05)$ \\
\hline \multirow{4}{*}{$\begin{array}{l}\text { Wine involvement items } \\
\text { (mean, S.D.) }\end{array}$} & I have a strong interest in wine. & $3.55(1.21)$ & $4.73(1.04)$ \\
\hline & $\begin{array}{l}\text { I select the wines I purchase very } \\
\text { carefully. }\end{array}$ & $3.48(1.24)$ & $4.23(1.05)$ \\
\hline & $\begin{array}{l}\text { I do not need a special occasion } \\
\text { to drink wine. }\end{array}$ & $3.66(1.26)$ & $4.16(1.22)$ \\
\hline & I like giving wine as a gift. & $3.59(1.23)$ & $4.07(1.13)$ \\
\hline $\begin{array}{l}\text { Wine involvement overall } \\
\text { average score }\end{array}$ & & $3.57(1.03)$ & $4.20(0.94)$ \\
\hline \multirow{2}{*}{$\begin{array}{l}\text { Attention to wine labeling } \\
\text { (mean, S.D.) }\end{array}$} & Front label & $3.73(1.16)$ & $4.21(0.98)$ \\
\hline & Back label & $3.80(1.26)$ & $4.21(1.03)$ \\
\hline
\end{tabular}

Statistically significant differences between Italy and Spain at the ${ }^{* * *} p \leq 0.01$ according to one-way ANOVA

\section{Natural wine information and perception}

In order to analyze the self-perceived information about natural wine, we asked wine consumers to indicate their level of information also with respect to organic and biodynamic wines. Italian wine consumers consider themselves not very informed about the three wines considered. However, they feel more informed about organic wine $(M$ $=2.96)$ than natural wine $(M=2.88)$, while biodynamic is in absolute the less known

Table 3 Respondents' natural product interest, mean values (S.D.)

\begin{tabular}{lll}
\hline & Italy $(\boldsymbol{n}=\mathbf{5 0 1})$ & Spain $(\boldsymbol{n}=\mathbf{5 2 7})$ \\
\hline I try to eat foods that do not contain additives. ${ }^{* * *}$ & $3.33(1.34)$ & $3.74(1.28)$ \\
I do not care about additives in my daily diet. ${ }^{* * *}$ & $2.36(1.36)$ & $1.83(1.14)$ \\
I do not eat processed foods, because I do not know what they contain. & $2.68(1.22)$ & $2.98(1.28)$ \\
I would like to eat only organically grown vegetables. ${ }^{* * *}$ & $2.95(1.38)$ & $3.44(1.42)$ \\
Artificially flavored foods are not harmful for my health. ${ }^{* *}$ & $2.21(1.21)$ & $2.03(1.29)$ \\
Organically grown foods are not better for my health than those grown & $1.94(1.07)$ & $2.30(1.38)$ \\
conventionally.*** & & \\
$\boldsymbol{N P I}$ (overall average score $)^{\circ}$ & $2.93(1.66)$ & $2.66(1.80)$ \\
\hline
\end{tabular}

Statistically significant differences between Italy and Spain at ${ }^{* *} p \leq 0.05 ;{ }^{* * *} p \leq 0.01$ according to one-way ANOVA 
wine. Spanish consumers consider themselves quite informed about organic $(M=3.87)$ as well as about natural wine $(M=3.65)$.

In order to investigate the interviewees' perception of natural wine, we proposed seven items asking respondents to indicate the degree of adherence to their idea of natural wine. As reported in Table 4, Italian consumers perceive natural wine mainly as an environmentally friendly product $(M=3.46)$, which does not contain additives $(M=$ $3.42)$ and is made in an artisanal way $(M=3.26)$. Spanish respondents mostly perceive natural wine as a product that does not contain additives $(M=4.24)$ and without sulfites $(M=4.11)$, and also as organic $(M=3.60)$.

\section{Natural wine shopping and consumption behavior}

In both countries, the incidence of consumers that stated to consume natural wine is high, respectively almost $69 \%$ in Italy and $78 \%$ in Spain. However, analyzing the frequency of consumption, as reported in Table 5, Italians drink natural wine more regularly than Spaniards. Indeed, $22.7 \%$ of Italian respondents stated to drink natural wine at least once a week, while $15.7 \% 2-3$ times a week and $7.8 \%$ on a daily basis. In Spain, respondents stated to drink natural wine mainly at least once a year $(35.3 \%)$ and at least once a month (33.1\%).

Regarding the self-reported motivations of natural wine consumption, in Italy, healthiness results are the core reason $(M=3.60)$, followed by handcrafted $(M=3.53)$ and sustainability $(M=3.33)$. In Spain, the handcrafted is the main reason to consume natural wine $(M=3.65)$, followed by sustainability $(M=3.49)$. In both countries, the statement "Natural wine makes me less drunk" and "Natural wine is easier to drink" are the least important motivations.

\section{Drivers of natural wine consumption}

In order to explore the drivers that affect natural wine consumption frequency, two ordered logistic regressions were performed considering in each country only individuals who have reported to drink natural wine (i.e., 344 in Italy and 411 in Spain). The frequency of consumption is the dependent variable of the models (Cameron and Trivedi 2005; McFadden 2001), while the explanatory variables (identified by a stepwise

Table 4 Self-reported information and natural wine perception, mean values (S.D.)

\begin{tabular}{llll}
\hline & & Italy $(\boldsymbol{n}=\mathbf{5 0 1})$ & Spain $(\boldsymbol{n}=\mathbf{5 2 7})$ \\
\hline $\begin{array}{l}\text { Self-reported degree of } \\
\text { information about... } \\
\text { (mean, S.D.) }\end{array}$ & Natural wine*** & $2.88(1.33)$ & $3.65(1.30)$ \\
& Biodynamic wine*** & $2.45(1.39)$ & $3.54(1.39)$ \\
Organic wine & Natural wine perceptions \\
(mean, S.D.) & Natural wine is environmental friendly. & $2.96(1.33)$ & $3.87(1.16)$ \\
& Natural wine does not contain added sulfites. & $2.98(1.35)$ & $4.11(1.15)$ \\
& Natural wine is organic. & $2.87(1.30)$ & $3.60(1.28)$ \\
& Natural wine does not contain additives. & $3.42(1.26)$ & $4.24(1.08)$ \\
& Natural wine is locally produced. & $2.74(1.32)$ & $2.97(1.45)$ \\
& Natural wine is handcrafted. & $3.26(1.29)$ & $3.78(1.30)$ \\
& Natural wine is like a wine produced by our & $2.71(1.33)$ & $3.31(1.39)$ \\
& grandparents. & & \\
\hline
\end{tabular}

Statistically significant differences between Italy and Spain at the ${ }^{* * *} p \leq 0.01$ according to one-way ANOVA 
Table 5 Natural wine drinking frequency and consumption motivations

\begin{tabular}{llll}
\hline & & Italy $(\boldsymbol{n}=\mathbf{3 4 4})$ & Spain $(\boldsymbol{n}=\mathbf{4 1 1})$ \\
\hline Natural wine consumption frequency (\%) & At least once a year & 21.5 & 35.3 \\
& At least once a month & 32.3 & 33.1 \\
& At least once a week & 22.7 & 14.8 \\
& 2-3 times a week & 15.7 & 11.2 \\
& Daily & 7.8 & 5.6 \\
Natural wine consumption motivations & Natural wine is healthier. & $3.60(1.20)$ & $3.43(1.43)$ \\
(mean value, S.D.) & Natural wine makes me less & $2.13(1.16)$ & $1.94(1.24)$ \\
& drunk. & & \\
& Natural wine causes less & $2.34(1.29)$ & $2.48(1.43)$ \\
& hangover. & & \\
& Natural wine is trendy. & $2.41(1.39)$ & $2.23(1.37)$ \\
& Natural wine is easier to drink. & $2.13(1.17)$ & $2.23(1.36)$ \\
& Natural wine tastes better. & $3.00(1.29)$ & $2.41(1.35)$ \\
& Natural wine is sustainable. & $3.33(1.24)$ & $3.49(1.38)$ \\
& Natural wine is handcrafted. & $3.53(1.21)$ & $3.65(1.25)$ \\
\hline
\end{tabular}

selection procedure) ${ }^{2}$ are (i) demographics (gender and age), (ii) variables related to wine drinking behavior (frequency and involvement), (iii) attention towards wine label information (back and front), (iv) self-reported information about natural wine and about organic wine, (v) natural product interest, and (vi) natural wine consumption motivations.

Results from the two ordered logistic regression models are reported as odds ratio with 95\% confidence intervals in Table 6. Briefly, an odds ratio greater than 1 indicates that higher values on the independent variable make it more likely that respondents will be in a higher category of the natural wine consumption frequency. An odds ratio lower than 1 indicates that a higher value of independent variable increases the likelihood of participants to be in the current consumption frequency level or lower (Table 8 in Appendix reports coefficients and standard errors).

Considering the influence of variables related to wine habits, the overall results show that wine consumption frequency is a key driver of natural wine consumption, both in Italy and in Spain. The more individuals consume wine regularly in general terms, the more they tend to consume natural wine frequently. Contrary, if we consider wine involvement level, we notice that in both countries, the higher level of involvement leads to a lower consumption frequency of natural wine. This suggests that consumers that perceive to be more interested in wine consume natural wine less frequently. Remarkable results arise also in relation to the attention paid by respondents to wine label information. Both in Italy and in Spain, the degree of attention to information on the front label negatively affects the natural wine consumption frequency. In other words, the more consumers are attentive towards front label information, the lower is their frequency of natural wine consumption. Nevertheless, in Spain, back label information attention positively affects natural wine consumption. This is probably due to the fact

\footnotetext{
${ }^{2}$ The selection has been performed to sort out irrelevant explanatory variables in order to improve accuracy of the effect estimates of the main interest and obtain interpretable, practically applicable models (VanderWeele and Shpitser 2011).
} 
Table 6 Odds ratio of the selected coefficients (95\% Cl)

\begin{tabular}{|c|c|c|c|c|}
\hline & \multicolumn{2}{|l|}{ Italy } & \multicolumn{2}{|l|}{ Spain } \\
\hline & Odds ratio & Std. Err. & Odds ratio & Std. Err. \\
\hline Wine drinking frequency & $2.329^{* * *}$ & 0.245 & $1.944^{* * *}$ & 0.213 \\
\hline Age & $0.980^{* *}$ & 0.008 & n.s. & \\
\hline Male & $1.330^{*}$ & 0.288 & n.s. & \\
\hline Wine involvement & $0.814^{*}$ & 0.100 & $0.807^{*}$ & 0.090 \\
\hline Sustainability motivation & $1.02^{*}$ & 0.001 & $1.01^{* * *}$ & 0.001 \\
\hline Hedonistic motivation & n.s. & & $1.00^{* * *}$ & 0.001 \\
\hline Front label attention & $0.736^{* * *}$ & 0.076 & $0.734^{* *}$ & 0.087 \\
\hline Back label attention & n.s. & & $1.301^{* *}$ & 0.159 \\
\hline Self-reported natural wine information & $1.516^{* * *}$ & 0.191 & $1.202^{*}$ & 0.143 \\
\hline Self-reported organic wine information & $0.785^{*}$ & 0.100 & n.s. & \\
\hline Natural product interest & $1.326^{*}$ & 0.234 & $1.266^{*}$ & 0.169 \\
\hline
\end{tabular}

Notes: Asterisks represent statistically significant at the levels: ${ }^{*} p \leq 0.1 ;{ }^{* *} p \leq 0.05 ;{ }^{* *} p \leq 0.01 ; n$. s., not statistically significant. Brant tests have verified that the proportional odds assumption (or the parallel regression assumption) was not violated for the two regression models. To exclude multicollinearity issues, correlation matrixes were computed and the variance inflation factor (VIF) was calculated to check potential correlations among independent variables of both models. Falsification tests were also performed, finding no significant effects of the control variables on alternative outcomes

that generally, back labels hold a greater amount of information on the natural characteristics of wines.

Furthermore, and not surprisingly, natural product interest is an important driver of natural wine consumption in both countries. As reported in Table 6, the higher positive attitude towards natural products increases natural wine consumption frequency, with a similar extent in Italy and Spain. Considering variables specifically related to natural wine, the results show that the degree of self-reported perceived information of natural wine positively affects the consumption frequency, in both Italy and Spain. It is worth highlighting that in Italy, self-reported information of organic wine negatively affects natural wine consumption frequency. This reveals that consumers who think of themselves to be informed about organic wine consume natural wine less regularly.

Natural wine motivations also influence consumption frequency. In particular, in Italy, the reasons linked to the sustainability aspects of natural wine positively affect consumption. In Spain, the frequency of consumption is positively influenced by both sustainability and hedonistic motivations. Considering the influence of individual sociodemographic characteristics, age and gender affect the consumption frequency of natural wine in Italy. In particular, younger consumers tend to consume natural wine more frequently, as well as males as compared to females. On the contrary, sociodemographic variables do not influence natural wine consumption frequency among Spanish respondents.

\section{Discussion}

Results from the present study confirm the soaring interest of Italian and Spanish consumers towards natural wine; indeed, in both countries, the incidence of respondents that self-reported consumption of this product was high. The findings also reveal some differences between Italian and Spanish consumers regarding the drivers that affect natural wine consumption frequency. 
According to our outcomes, Italians state to drink natural wine more regularly than Spaniards, although the self-reported degree of information about natural wine is higher in Spain. However, with specific reference to the Spanish market, a recent study from Fernández (2019) showed that the lack of consumer understanding of natural wines is considered a key challenge for Spanish natural wine producers.

Further, consumers in both countries showed a higher level of perceived information about organic wine compared to natural. This is probably due to the higher awareness of organic wine, which can be explained by the existence of a regulated certification with great visibility given that it is carried by other food products for more than 30 years. Our results are in line with previous research on the confusion between natural, biodynamic, and organic wine (Urdapilleta et al. 2021; Delmas and Lessem 2017; Sogari et al. 2016), due to the lack of a regulated natural wine certification and the uncertainty caused by the absence of a wine ingredient list (Pabst et al. 2021).

In terms of naturalness perception, our findings reveal the differences among the two countries (as noted also by Staub et al. 2020). Italians perceive natural wine as environmentally friendly and without additives, while in Spain, it is mainly considered as without added sulfites. With reference to Italy, the results confirm previous research (Galati et al. 2019; Migliore et al. 2020) showing that natural wine preferences rely on consumers' attitudes towards the environment and health. While for Spain, the natural wine perception might be explained by the surge in greenwashing strategies by winemaking companies aimed to equate wine without added sulfites with environmentally sustainable and healthy wines (Costanigro et al. 2014; D’Amico et al. 2016). Indeed, confusion among consumers is currently fostered by several diverse natural wine claims. For instance, the Italian associations VAN, VinNature, and ViniVeri in Italy allow winemakers to add a maximum of 40, 50 , and $80 \mathrm{mg} / \mathrm{l}$ of sulfites, respectively, while other natural winemakers' associations in Europe, from the French SAINS to the Spanish AVN and alternative Italian natural wine groups, advocate that natural wines should be without added sulfites.

Additionally, the results show that different perceptions also lead to diverse motivations to drink natural wine. In Italy, natural wine consumers are mainly guided by sustainability concerns, confirming previous research (Forbes et al. 2009; Galati et al. 2019; Migliore et al. 2020), and underlining that sustainability is increasingly becoming a factor of competitive advantage (Pomarici and Vecchio 2019). While, in Spain, natural wine consumers are both guided by sustainability and hedonistic motivations, wine drinking is widely considered among Spaniards as a beverage associated with lifestyle and socio-cultural aspects, and its consumption is regarded as a hedonic experience (Williams and Atwal 2013; Alonso González and Parga-Dans 2018). Furthermore, this finding corroborates the results of Jorge et al. (2020) who recently revealed, in their wine laboratory experiment, that Spanish consumers' preferences for organic wine are strongly related to tasty attitude, revealing that an egocentric perspective affects consumers' decisions.

Consistent with previous evidences (Galati et al. 2019; Migliore et al. 2020; Bazzani et al. 2020), our results confirm that in both countries, a higher positive attitude towards natural products increases natural wine consumption frequency. This outcome underlines that the growing attention of consumers towards healthy eating is also affecting wine choices, as recently suggested by several scholars (Pabst et al. 2019; Bazzani et al. 2020; Pabst et al. 2021). 
Current results also show that natural wine consumption is strongly related to wine consumption frequency and involvement. In both countries, the more individuals consume wine regularly, the more frequently they tend to consume natural wine. On the contrary, a higher level of involvement leads to a lower consumption frequency of natural wine. This is partially in contrast with Staub et al. (2020), who found that participants with a high level of wine involvement perceived naturalness as significantly more important than people with low involvement. However, in line with Sáenz-Navajas et al. (2016), it could be argued that the higher level of involvement leads consumers to see wine more as a hedonic beverage. This would lead their consumption choices towards extrinsic factors such as origin, terroir, grape variety, or harvest and less towards the intrinsic factors that are the focus of natural wines. In this regard, our findings indicate that lower levels of wine involvement lead to higher natural wine consumption frequency in both countries. This could be related to individuals' search for healthier foods, which is less influenced by the product's external cues. In the case of Italy, this particular result is also found by Migliore et al. (2020) who showed that the presence of an appellation of origin on the wine label negatively impacts WTP for natural wine.

Among the socio-demographic characteristics, the results show that younger Italian drinkers tend to consume natural wine more frequently, confirming evidences from previous researches that revealed the growing popularity of these wines especially among Millennials (Fernández 2019; Galati et al. 2019).

\section{Conclusion}

The current outcomes corroborate the idea that the importance of food naturalness varies across countries and cultures (Rozin et al. 2004). However, taking into consideration the natural wine, other reasons can be related to different positions adopted by particular associations across nations and the dissimilar stage of market development, which is more lively in Italy in terms of existing associations, distributors, and winemakers (Wine Intelligence 2021). Nevertheless, Spain is recently catching up and rapidly growing in terms of natural wine producers and in terms of natural wine value chain (Fernández 2019).

Our findings are subject to several limitations. First, we collected data from a convenience sample of self-selected wine consumers, which limits the potential to generalize our findings to the wine consumer populations of Italy and Spain at large. Future studies should aim to use larger, representative wine consumer samples in both countries, offering more general findings. Second, the present study, as most similar research, was based on self-reported behavior that likely suffers from social desirability bias (Fisher 1993). Furthermore, the lack of a clear and regulated definition of natural wine allows individuals to interpret its meaning in very different (and personal) manners, thus potentially leading to inconsistent measurements among respondents. The social effects of the official recognition of natural wine in France will surely bring consequences worth exploring. Finally, the pseudo- $\mathrm{R}^{2}$ values in the regression models were low, which implies that other psychological, environmental, and personal factors influence natural wine consumption frequency. Further research should try to identify other potential determinants of natural wine consumption to provide a more complete overview of consumer drivers, and could verify the existence of homogeneous consumer segments across the two countries in order to better outline the features of this new promising market segment. 


\section{Appendix}

Table 7 Matrix of the rotated components

\begin{tabular}{lll}
\hline & Factor loadings \\
\hline Natural wine is healthier & .791 & .256 \\
Natural wine makes me less drunk & .335 & .762 \\
Natural wine causes less hangover & .417 & .726 \\
Natural wine is trendy & -.455 & .559 \\
Natural wine is easier to drink & .358 & .716 \\
Natural wine tastes better & .364 & .428 \\
Natural wine is sustainable & .810 & .179 \\
Natural wine is handcrafted & .735 & .221 \\
Variance explained \% & $36.47 \%$ & $28.28 \%$ \\
Total variance \% & & $\mathbf{6 4 . 7 5 \%}$ \\
\hline
\end{tabular}

Notes: Extraction method: principal components analysis. Rotation methods: varimax with Kaiser normalization

Table 8 Ordered logistic regressions coefficients and standard errors

\begin{tabular}{|c|c|c|c|c|}
\hline & Italy & & Spain & \\
\hline & Coef. & Std. Err. & Coef. & Std. Err. \\
\hline Wine drinking frequency & $0.845^{* * *}$ & 0.105 & $0.665^{* * *}$ & 0.109 \\
\hline Age & $-0.019^{* *}$ & 0.008 & 0.001 & 0.009 \\
\hline Male & $0.285^{*}$ & 0.207 & 0.065 & 0.215 \\
\hline Wine involvement & $-0.205^{*}$ & 0.123 & $-0.214^{*}$ & 0.111 \\
\hline Sustainability motivation & $0.006^{* * *}$ & 0.001 & $0.006^{* * *}$ & 0.001 \\
\hline Hedonistic motivation & 0.001 & 0.001 & $0.004^{* * *}$ & 0.001 \\
\hline Front label attention & $-0.305^{* * *}$ & 0.103 & $-0.308^{* *}$ & 0.119 \\
\hline Back label attention & -0.017 & 0.103 & $0.263^{* *}$ & 0.122 \\
\hline Self-reported natural wine information & $0.416^{* * *}$ & 0.126 & $0.184^{*}$ & 0.121 \\
\hline Self-reported organic wine information & $-0.241^{* * *}$ & 0.128 & -0.052 & 0.136 \\
\hline Natural product interest & $0.282^{*}$ & 0.172 & $0.236^{*}$ & 0.133 \\
\hline Number of observations & 344 & & 411 & \\
\hline$L R X^{2}(11)$ & 136.16 & & 119.63 & \\
\hline Prob $>x^{2}$ & 0.0000 & & 0.0000 & \\
\hline Log likelihood & -455.627 & & -525.080 & \\
\hline Pseudo $R^{2}$ & 0.1300 & & 0.1023 & \\
\hline
\end{tabular}

Notes: Asterisks represent statistically significant at the levels: ${ }^{*} p \leq 0.1 ;{ }^{* *} p \leq 0.05 ;{ }^{* * *} p \leq 0.01$ 


\section{Abbreviations}

AVN: Association des Vins Naturels; CSIC: Spanish National Research Council; EFSA: European Food Safety Authority; EU: European Union; OIV: Organisation Internationale de la vigne et du vin; PCA: Principal component analysis; SAIN S: Sans Aucun Intrant Ni Sulfite; VAN: Vignaioli Artigianali Naturali

\section{Acknowledgements}

This paper was supported by the Spanish Plan of Innovation, Technical and Scientific Research 2017-2020 - Ramón and Cajal Ref. RYC2018-024025-I. The dissemination of the survey in Spain was supported by the Observatorio Español del Mercado del Vino (OEMV), Vitivin, Spanish Wine Lover, Gourmet Hunters, Bodegas.bio, Indie Spanish Wines, Vinos Utópicos, Junguitu ¿hablamos de vino?, El Sumiller, and Vinófilos. We acknowledge the support of the publication fee by the CSIC Open Access Publication Support Initiative through its Unit of Information Resources for Research (URICI).

\section{Authors' contributions}

All authors contributed to the research design and data collection. Analysis and interpretation were done by RV and AA. Drafting of the manuscript was done by AA and RV. Review and comments were done by EP and AG. All authors read and approved the final manuscript

\section{Funding}

This paper was supported by the Spanish Plan of Innovation, Technical and Scientific Research 2017-2020 - Ramón and Cajal Ref. RYC2018-024025-I.

\section{Availability of data and materials}

The datasets used and/or analyzed during the current study are available from the corresponding author on reasonable request.

\section{Declarations}

\section{Competing interests}

The authors declare that they have no competing interests.

\section{Author details}

'Department of Agricultural Science, University of Naples Federico II (Italy), Via Università, 100, Portici, 80055 Naples, Italy. ${ }^{2}$ Instituto de Productos Naturales y Agrobiología (IPNA-CSIC), Avda. Astrofísico Francisco Sánchez, 3, 38206 La Laguna, Santa Cruz de Tenerife, Spain. "Department of Economic and Legal Studies, University of Naples "Parthenope" (Italy), Via Parisi, 13, 80133 Naples, Italy.

Received: 22 March 2021 Revised: 4 May 2021

Accepted: 27 May 2021 Published online: 05 October 2021

\section{References}

Alonso González P, Parga-Dans E (2018) The 'terroirist' social movement: the reawakening of wine culture in Spain. J Rural Stud 61:84-196 https://doi.org/10.1016/j.jrurstud.2018.04.014

Alonso González P, Parga-Dans E (2020) Natural wine: do consumers know what it is, and how natural it really is? J Clean Prod 251:119635 https://doi.org/10.1016/j.jclepro.2019.119635

Amato M, Ballco P, López-Galán B, De Magistris T, Verneau F (2017) Exploring consumers' perception and willingness to pay for "non-added sulphite" wines through experimental auctions: a case study in Italy and Spain. Wine Econ Policy 6(2): 146-154 https://doi.org/10.1016/j.wep.2017.10.002

Annunziata A, Pomarici E, Vecchio R, Mariani A (2016) Nutritional information and health warnings on wine labels: exploring consumer interest and preferences. Appetite 106:58-69 https://doi.org/10.1016/.appet.2016.02.152

Asioli D, Aschemann-Witzel J, Caputo V, Vecchio R, Annunziata A, Næs T, Varela P (2017) Making sense of the "clean label" trends: a review of consumer food choice behavior and discussion of industry implications. Food Res Int 99(Pt 1):58-71 https://doi.org/10.1016/j.foodres.2017.07.022

Bazzani C, Capitello R, Ricci EC, Scarpa R, Begalli D (2020) Nutritional knowledge and health consciousness: do they affect consumer wine choices? Evidence from a survey in Italy. Nutrients 12(1):84 https://doi.org/10.3390/nu12010084

Black RE (2013) Vino Naturale: tensions between nature and technology in the glass. In: Black RE, Ulin RC (eds) Wine and culture: vineyard to glass. Bloomsbury, London, pp 279-294. https://doi.org/10.5040/9781350042254.ch-015

Cameron AC, Trivedi PK (2005) Microeconometrics: methods and applications. Cambridge University press. https://doi.org/1 $0.1017 /$ CBO978051181124

Caracciolo F, Vecchio R, Lerro M, Migliore G, Schifani G, Cembalo L (2019) Natural versus enriched food: evidence from a laboratory experiment with chewing gum. Food Res Int. 122:87-95 https://doi.org/10.1016/j.foodres.2019.03.069

Catellani A (2015) Vin nature et vin biologique: observations sur quelques aspects de la communication Enologique. Lexia 19:465

Chambers E, Castro M (2018) What is "natural"? Consumer responses to selected ingredients. Foods 7(4) https://doi.org/10.33 90/foods7040065

Chrysochou P, Krystallis A, Mocanu A, Leigh Lewis R (2012) Generation Y preferences for wine: an exploratory study of the US market applying the best-worst scaling. Br Food J. 114(4):516-528 https://doi.org/10.1108/00070701211219531

Costanigro M, Appleby C, Menke SD (2014) The wine headache: consumer perceptions of sulfites and willingness to pay for non-sulfited wines. Food Qual Prefer. 31:81-89 https://doi.org/10.1016/j.foodqual.2013.08.002

D’Amico M, Di Vita G, Monaco L (2016) Exploring environmental consciousness and consumer preferences for organic wines without sulfites. J Clean Prod. 120:64-71 https://doi.org/10.1016/j.jclepro.2016.02.014 
De Salvo M, Capitello R, Begalli D (2019) How CS can be used for gaining info about consumers and the market? In: Santini C (ed) Case Studies in the Wine Industry 157-166. Woodhead Publishing. https://doi.org/10.1016/B978-0-08-100944-4 $00012-4$

Delmas MA, Lessem N (2017) Eco-premium or eco-penalty? Eco-labels and quality in the organic wine market. Bus Soc 56(2): 318-356 https://doi.org/10.1177/0007650315576119

EFSA (2019). Special Eurobarometer - Wave EB91.3. Food Safety in the EU. EFSA. European Commissionhttps://www.efsa. europa.eu/sites/default/files/corporate_publications/files/Eurobarometer2019_Food-safety-in-the-EU_Full-report.pdf

Feiring A, Choksi N (2019) Natural wine for the people: what it is, where to find it, how to love it. Ten Speed Press, California

Fernández RF (2019) Finding common ground: the need for cooperation and collaboration in the Spanish Natural Wine Industry. Wine Bus J. 3(1):65-93

Fisher RJ (1993) Social desirability bias and the validity of indirect questioning. J Consum Res 20(2):303-315.

Forbes SL, Cohen DA, Cullen R, Wratten SD, Fountain J (2009) Consumer attitudes regarding environmentally sustainable wine: an exploratory study of the New Zealand marketplace. J Clean Prod 17(13):1195-1199 https://doi.org/10.1016/j. jclepro.2009.04.008

Galati A, Schifani G, Crescimanno M, Migliore G (2019) "Natural wine" consumers and interest in label information: an analysis of willingness to pay in a new Italian wine market segment. J Clean Prod. 227:405-413 https://doi.org/10.1016/j.jclepro.2 019.04.219

Goode J, Harrop S (2011) Authentic wine: toward natural and sustainable winemaking. University of California Press. https:// doi.org/10.1525/9780520949690

Grunert KG, Hieke S, Juhl HJ (2018) Consumer wants and use of ingredient and nutrition information for alcoholic drinks: a cross-cultural study in six EU countries. Food Qual Prefer 63:107-118 https://doi.org/10.1016/j.foodqual.2017.08.005

Hemmerling S, Canavari M, Spiller A (2016) Preference for naturalness of European organic consumers: first evidence of an attitude-liking gap. Br Food J 118(9):2287-2307 https://doi.org/10.1108/BFJ-11-2015-0457

Jorge E, Lopez-Valeiras E, Gonzalez-Sanchez MB (2020) The role of attitudes and tolerance of ambiguity in explaining consumers' willingness to pay for organic wine. J Clean Prod. 257:120601 https://doi.org/10.1016/j.jclepro.2020.120601

Kelley K, Hyde J, Bruwer J (2015) US wine consumer preferences for bottle characteristics, back label extrinsic cues and wine composition. Asia Pac J Mark Logistics

Legeron I (2018) Natural wine: an introduction to organic and biodynamic wines made naturally. London: Ryland Peters \& Small

Lockshin L, Quester P, Spawton T (2001) Segmentation by involvement or nationality for global retailing: a crossnational comparative study of wine shopping behaviours. J Wine Res. 12(3):223-236 https://doi.org/10.1080/095712 60120106848

Maykish A, Rex R, Sikalidis AK (2021) Organic winemaking and its subsets; biodynamic, natural, and clean wine in California. Foods https://doi.org/10.3390/foods10010127 10(1)

McFadden D (2001) Economic choices. Am Econ Rev 91(3):351-378. https://doi.org/10.1257/aer.91.3.351

Migliore G, Thrassou A, Crescimanno M, Schifani G, Galati A (2020) Factors affecting consumer preferences for "natural wine": an exploratory study in the Italian market. Br Food J. 122(8):2463-2479 https://doi.org/10.1108/BFJ-07-2019-0474

Mueller S, Lockshin L, Saltman Y, Blanford J (2010) Message on a bottle: the relative influence of wine back label information on wine choice. Food Qual Prefer. 21(1):22-32. https://doi.org/10.1016/j.foodqual.2009.07.004

Nossiter J (2019) Cultural insurrection: a manifesto for the arts, agriculture, and natural wine. Other Press, New York

OIV (2020). State of the Vitivinicultural sector in 2019. Retrieved online at: https://www.oiv.int/js/lib/pdfjs/web/viewer html?file=/public/medias/7284/presentation-oiv-press-conference-april-2020.pdf

Pabst E, Corsi AM, Vecchio R, Annunziata A, Loose SM (2021) Consumers' reactions to nutrition and ingredient labelling for wine-a cross-country discrete choice experiment. Appetite 156 https://doi.org/10.1016/j.appet.2020.104843:104843

Pabst E, Szolnoki G, Loose SM (2019) The effects of mandatory ingredient and nutrition labelling for wine consumers. A qualitative study. Wine Econ Pol 8(1):5-15. https://doi.org/10.1016/j.wep.2019.02.001

Pappalardo G, Di Vita G, Zanchini R, La Via G, D'Amico M (2019) Do consumers care about antioxidants in wine? The role of naturally resveratrol-enhanced wines in potential health-conscious drinkers' preferences. Br Food J 122(8):2689-2705 https://doi.org/10.1108/BFJ-06-2019-0453

Parga-Dans E, Alonso González P (2018) From paper to soil: the impact of new EU alcoholic drinks labeling regulations for wine regions. J Consum Prot Food Saf 13(1):89-94 https://doi.org/10.1007/s00003-017-1135-8

Pomarici E, Asioli D, Vecchio R, Næs T (2018) Young consumers' preferences for water-saving wines: an experimental study. Wine Econ Policy 7(1):65-76. https://doi.org/10.1016/j.wep.2018.02.002

Pomarici E, Vecchio R (2019) Will sustainability shape the future wine market? Wine Econ. Policy 8(1):1-4 https://doi.org/10.1 016/j.wep.2019.05.001

Roininen K, Lähteenmäki L, Tuorila H (1999) Quantification of consumer attitudes to health and hedonic characteristics of foods. Appetite 33(1):71-88 https://doi.org/10.1006/appe.1999.0232

Roman S, Sánchez-Siles LM, Siegrist M (2017) The importance of food naturalness for consumers: results of a systematic review. Trends Food Sci Tech. 67:44-57 https://doi.org/10.1016/.itifs.2017.06.010

Rozin P (2006) Naturalness judgments by lay Americans: Process dominates content in judgments of food or water acceptability and naturalness. Judgment and Decision Making 1(2):91

Rozin P, Fischler C, Shields-Argeles C (2012) European and American perspectives on the meaning of natural. Appetite 59(2): 448-455 https://doi.org/10.1016/j.appet.2012.06.001

Rozin P, Spranca M, Krieger Z, Neuhaus R, Surillo D, Swerdlin A, Wood K (2004) Preference for natural: instrumental and ideational/moral motivations, and the contrast between foods and medicines. Appetite 43(2):147-154

Sáenz-Navajas MP, Avizcuri JM, Echávarri JF, Ferreira V, Fernández-Zurbano P, Valentin D (2016) Understanding quality judgements of red wines by experts: effect of evaluation condition. Food Qual Prefer. 48:216-227 https://doi.org/10.1016/ j.foodqual.2015.10.001

Schäufele I, Hamm U (2017) Consumers' perceptions, preferences and willingness-to-pay for wine with sustainability characteristics: a review. J Clean Prod. 147:379-394 https://doi.org/10.1016/j.jclepro.2017.01.118 
Siegrist M, Hartmann C (2020) Consumer acceptance of novel food technologies. Nature Food 1(6):343-350 https://doi.org/1 $0.1038 / 543016-020-0094-x$

Sogari G, Mora C, Menozzi D (2016) Factors driving sustainable choice: the case of wine. Br Food J. 118(3):632-646 https:// doi.org/10.1108/BFJ-04-2015-0131

Staub C, Michel F, Bucher T, Siegrist M (2020) How do you perceive this wine? Comparing naturalness perceptions of Swiss and Australian consumers. Food Qual Prefer 79 https://doi.org/10.1016/j.foodqual.2019.103752:103752

Urdapilleta I, Demarchi S, Parr WW (2021) Influence of culture on social representation of wines produced by various methods: natural, organic and conventional. Food Qual Prefer 87 https://doi.org/10.1016/.jfoodqual.2020.104034:104034

VanderWeele TJ, Shpitser I (2011) A new criterion for confounder selection. Biometrics 67(4):1406-1413. https://doi.org/10.32 80/ecag1-2020oa1006910.1111/j.1541-0420.2011.01619.x

Vecchio R, Caso G, Cembalo L, Borrello M (2020) Is respondents' inattention in online surveys a major issue for research? Economia Agro-alimentare Food Econ 22(1). https://doi.org/10.3280/ecag1-2020oa10069/10.3280/ecag1-2020oa10069

Williams A, Atwal G (2013) The hedonistic consumption of luxury and iconic wines. In: Luxury marketing. Gabler Verlag, Wiesbaden, pp 379-393

Wine Intelligence (2021). Wine Intelligence Global SOLA report: opportunities for sustainable and organic wine 2021 report. https:/www.wineintelligence.com/downloads/global-sola-2021/

\section{Publisher's Note}

Springer Nature remains neutral with regard to jurisdictional claims in published maps and institutional affiliations.

Submit your manuscript to a SpringerOpen ${ }^{\circ}$ journal and benefit from:

- Convenient online submission

- Rigorous peer review

- Open access: articles freely available online

- High visibility within the field

- Retaining the copyright to your article

Submit your next manuscript at $\boldsymbol{\nabla}$ springeropen.com 